\title{
PELATIHAN PEMBUATAN ABON BANDENG BAGI MASYARAKAT DESA TENJOAYU KECAMATAN TANARA PROVINSI BANTEN
}

\begin{abstract}
Kurniasih Dwi Astuti ${ }^{*}$ Nining Widiya Ningsih ${ }^{2}$

Riyan Hidayatullah ${ }^{3}$

Sarah Nur Azizah ${ }^{4}$

Rini Soviana ${ }^{5}$

Ziva Maeko Pshayna Depari ${ }^{6}$

Alhan Ferdyawan Saputra ${ }^{7}$

Amara Dwi Rahmah ${ }^{8}$

Dhian Widya Astuti ${ }^{9}$

1,2,3,4,5,6,7,8,9Universitas Sultan Ageng Tirtayasa, Serang, Indonesia

nien rz@untirta.ac,id $1^{*}$

widianingsihnining98@gmail.com ${ }^{2)}$

ryanhihayatullah777@gmail.com ${ }^{3}$

sarahnurazizah501@gmail.com $^{4)}$

sovirini08@gmail.com ${ }^{5}$

zivamaeko99@gmail.com ${ }^{6}$

volatilezero90@gmail.com ${ }^{7}$

amaradwira@gmail.com ${ }^{8}$

widyad20@gmail.com ${ }^{\text {) }}$

Kata Kunci:

[Desa Tenjoayu, Abon Banden]

Abstrak: Desa Tenjo Ayu Kecamatan Tanara Kabupaten Serang Banten merupakan desa pesisir yang memiliki potensi lokal yaitu ikan bandeng. Selain itu, desa Tenjo Ayu, memiliki permasalahan di sektor lingkungan dan ekonomi. Kegiatan pengabdian kepada masyarakat ini bertujuan untuk menciptakan produk olahan ikan bandeng berupa Abon Bandeng melalui pemberdayaan masyarakat di desa Tenjo Ayu. Target khusus yang diharapkan dari kegiatan ini adalah memberikan pemahaman terkait pengolahan hasil tambak ikan bandeng menjadi produk baru yang memiliki nilai ekonomis yang tinggi. Kegiatan ini dilakukan selama 2 bulan secara daring dan luring dimana dalam kegiatan ini terdiri atas kegiatan pelatihan produksi abon bandeng, pengemasan, serta pemasaran produk baik online maupun offline. Hasil kegiatan ini berupa kemampuan masyarakat Desa Tenjo Ayu memproduksi Abon Bandeng, Mengemas dan memasarkannya, sehingga dapat menambah penghasilan dan meningkatkan ekonomi masyarakat.
\end{abstract}

Published by:

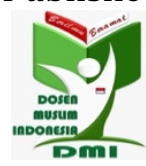

Copyright (C) 2021 The Author(s)

This article is licensed under CC BY 4.0 License

\section{(cc) $\mathrm{Br}$}

https://dmi-journals.org/jai/ 


\section{Pendahuluan}

Kecamatan Tanara merupakan kecamatan yang terletak di sebelah utara Kabupaten Serang dengan luas wilayah $33,73 \mathrm{Km}^{2}$, dengan batas wilayah administratif yaitu, Sebelah Utara berbatasan dengan Laut Jawa, Sebelah Selatan berbatasan dengan Kabupaten Tangerang, Sebelah Barat berbatasan dengan Kecamatan Carenang, Sebelah Timur berbatasan dengan Kecamatan Tirtayasa. Desa Tenjo Ayu merupakan salah satu Desa dari 9 Desa yang ada dikecamatan Tanara Kab. Serang, Provinsi Banten dengan luas wilayah $1.496 \mathrm{Ha}$, dengan batas wilayah administratif yaitu, Sebelah Utara berbatasan dengan Laut Jawa, Sebelah Selatan berbatasan dengan Desa Sukamanah, Sebelah Barat berbatasan dengan Desa Cerukcuk, Sebelah Timur berbatasan dengan Desa Tanara. Desa Tenjo Ayu merupakan suatu daerah dengan tingkat perekonomian masyarakat menengah ke bawah, hal ini dapat dilihat dari tingkat perekonomian Desa Tenjo Ayu, dimana mata pencaharian masyarakatnya berbeda-beda sesuai dengan kemampaun dibidangnya masing-masing (Astuti,2021)

Berdasarkan hasil observasi, Desa Tenjoayu merupakan desa yang memiliki potensi alam lokal yang melimpah salah satunya bandeng. Potensi lokal tersebut belum dimanfaatkan secara optimal oleh masyarakat setempat karena kurangnya skill serta pengetahuan dalam pengolahan. Pengusaha bandeng hanya menjual bahan baku dalam bentuk mentah tanpa proses terlebih dahulu.

Salah satu upaya yang dilakukan untuk mengatasi permasalahan tersebut adalah dengan diversifikasi pangan yaitu pengolahan bandeng menjadi produk baru yang bernilai jual tinggi. Selama ini tanpa kita sadari banhwa ikan bandeng banyak mengandung mineral dan kalsium yang tinggi (ainurrohma, 2017). Menurut Hafiludin (2015) Bandeng kaya akan protein (20-24\%), asam amino, asam lemak, mineral dan vitamin. Meskipun demikian masih banyak yang belum mengetahui dan masih sedikit yang memanfaatkannya. Oleh karena ituhasil produksi ikan bandeng yang melimpah dapat menjadi produk inovatif serta dapat memberikan solusi atas permasalahan ekonomi serta lingkungan di desa Tenjo Ayu. Sehubungan dengan hal tersebut, kegiatan ini perlu dilaksanakan. Kegiatan ini merupakan bentuk pengabdian kepada masyarakat sebagai implementasi dari Tri Dharma Perguruan Tinggi. Kegiatan ini bertujuan untuk memberikan pengetahuan tentang cara mengolah bandeng menjadi sebuah produk yang bernilai jual tinggi.

\section{Metode Pelaksanaan}

Kegiatan ini dilaksanakan pada juli-agustus 2021 bertempat di Desa Tenjoayu, Kecamatan Tanara Kabupaten Serang, Provinsi Banten. Kegiatan diawali dengan identifikasi masalah melalui kegiatan observasi di lokasi. Pelaksanaan program dimulai dengan sosialisasi kegiatan, kemudian dilakukan pembagian kelompok antar tim pelaksana dan ibu ibu pkk yang terdiri dari tim produksi, tim pengemasan dan tim pemasaran. Sasaran pelaksanaan kegiatan yaitu ibu-ibu pkk terutama masyarakat desa domas. Jumlah peserta yang mengikuti program ini kurang lebih 20 orang yang terdiri dari ibu-ibu pkk, masyarakat desa setempat, dan tim KKM Universitas Sultan Ageng Tirtayasa dengan tetap menerapkan protokol kesehatan. Metode kegiatan yang digunakan pada kegiatan pengabdian kepada masyarakat ini adalah dengan penyuluhan dan praktik langsung. 


\section{Hasil dan Pembahasan}

Berdasarkan hasil observasi yang dilakukan, terdapat banyak bandeng hasil tambak yang belum dimanfaatkan secara optimal oleh masyarakat setempat. Berdasarkan hal tersebut civitas academica tertarik untuk melaksanakan kegiatan KKM bidang pengabdian kepada masyarakat berupa pelatihan pembuatan olahan bandeng berupa abon bandeng bersama tim pelaksana dan ibu-ibu pkk serta masyarakat setempat yang dilaksanakan Juli-Agustus 2021. Adapun tahapan pelaksanaan pengabdian kepada masyarakat yaitu tahap persiapan, pelaksanaan dan evaluasi.

Pada Tahap persiapan, tim pelaksana Pengabdian kepada Masyarakat melakukan kesepakatan kerjasama bersama mitra yaitu ibu-ibu PKK dan masyarakat Desa Tenjoayu. Kemudian dilanjutkan ke tahap pelaksanaan kegiatan yang mana dilakukan dalam beberapa tahap yaitu tahap sosialisasi, tahap pelatihan pembuatan produk, tahap pelatihan pengemasan dan pemasaran.

\section{Tahap Sosialisasi Program Pembuatan Abon Bandeng}

Kegiatan sosialisasi diawali dengan menjelaskan program pengabdian kepada masyarakat serta menjelaskan terkait produk olahan bandeng ke ibu-ibu pkk dan masyarakat setempat. Hasil yang di dapatkan dari kegiatan tersebut yaitu pembentukan tim pelaksanaan program yang terdiri dari ibu-ibu pkk dan masyarakat desa domas dan tim dari Universitas Sultan Ageng Tirtayasa.

\section{Pembuatan Produk Abon Bandeng}

Abon merupakan jenis makanan yang banyak digemari. Abon yang beredar di pasaran biasanya terbuat dari daging sapi atau daging ayam. Bandeng merupakan salah satu komoditas yang strategis untuk memenuhi kebutuhan protein yang relative murah dan digemari oleh konsumen di Indonesia. Saat ini bandeng dapat dibudidayakan dengan menggunakan air tawar dan air payau. Bandeng kaya akan protein (20-24\%), asa, amino, asam lemak, mineral dan vitamin. Komposisi asam amino glutamate sebesar 1,386\%. (air tawar) dan 1,268\% (air payau), Asam lemak tak jenuh tertinggi oleat 31-32\%, mineral makro pada daging bandeng yaitu $\mathrm{Ca}, \mathrm{Mg}, \mathrm{Na}$ dan $\mathrm{K}$. Mineral mikronya terdiri dari $\mathrm{Fe}$, $\mathrm{Zn}, \mathrm{Cu}, \mathrm{Mn}$. Kandungan vitamin daging ikan bandeng meliputi vitamin A,B1, dan B12. (Hafiludin, 2015. Komposisi yang digunakan dalam pembuatan abon bandeng adalah ikan bandeng yang ditambah dengan bumbu bumbu seperti bawang putih, ketumbar, jinten, seraki, garam dan gula pasir.

Proses pembuatan abon bandeng diawali dengan pembersihan ikan bandeng bagian luar dan dalem, kemudian dibelah dan dibersihkan durinya. Kemudian ikan bandeng dikukus selama 25 menit. Tahapan berikutnya adalah ikan bandeng disuwir suwir dan menggiling ikan bandeng tersebut dalam mesin penggiling. Kemudian bumbu dihaluskan dan ditumis, lalu ikan bandeng yg telah dihalusnya dicampur dan diaduk dengan bumbu, dimasak hingga kering dan didinginkan. Setelah abon ikan bandeng matang dan dingin dimasukkan ke mesin spinner. Langkah akhir proses adalah pengemasan abon bandeng. 


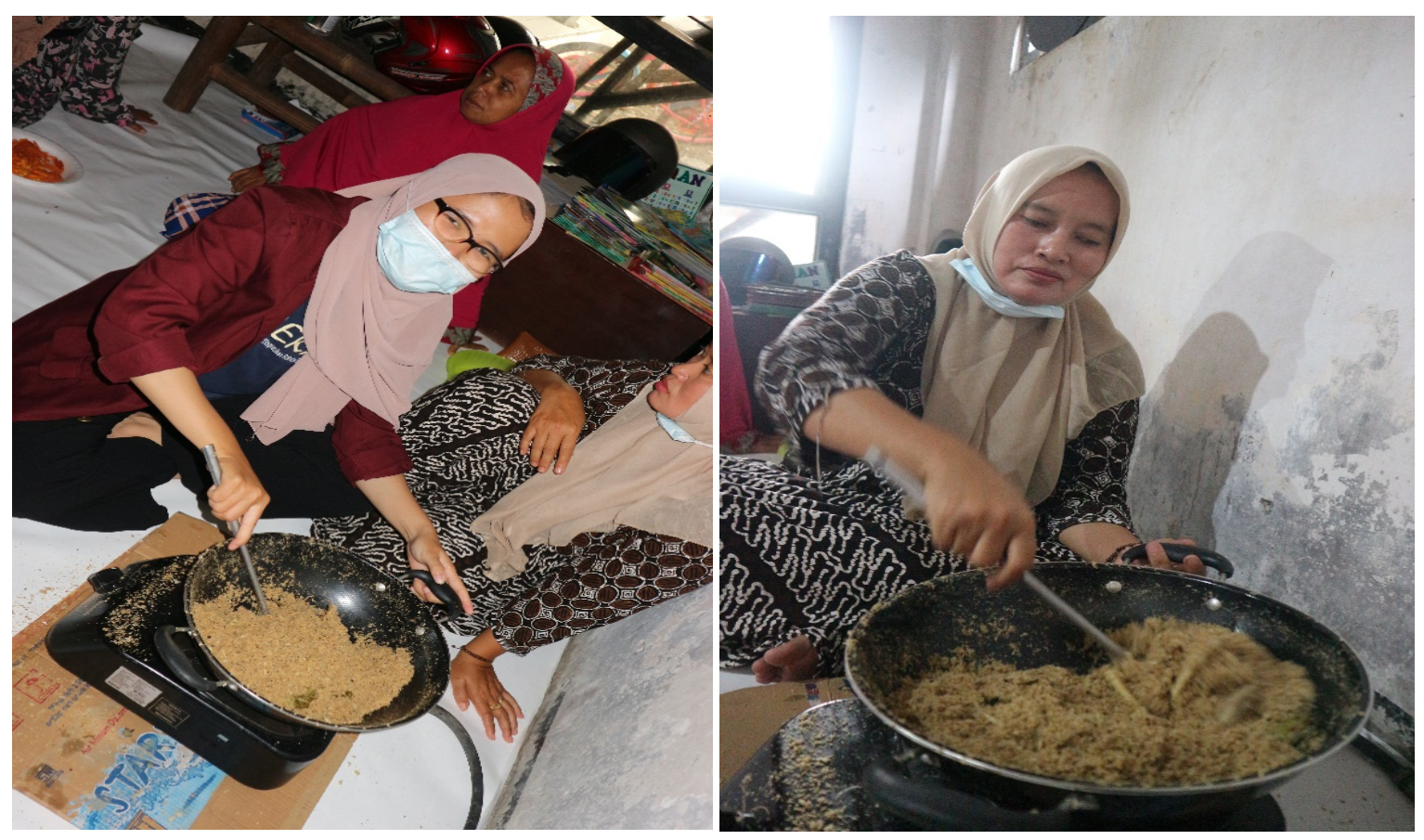

Gambar 1. Pembuatan Abon Bandeng
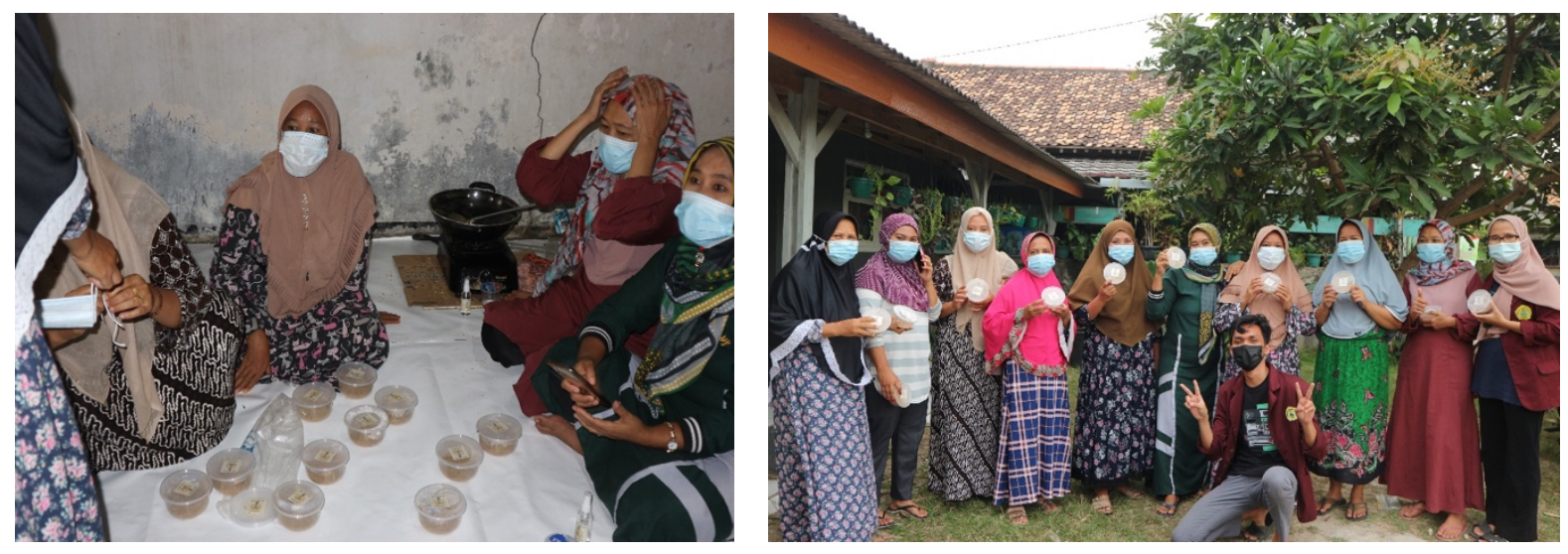

Gambar 2. Produk matang dan kemasan abon bandeng.

\section{Kesimpulan}

Hasil kegiatan pelatihan pemanfaatan bandeng hasil tambak warga menjadi produk abon bandeng telah dapat meningkatkan motivasi, inovasi, kreatifitas dan juga pendapatan warga Desa tenjoayu dengan adanya produk olahan baru dari bandeng. Sehingga harapannya produk baru olahan bandeng ini dapat dipasarkan seluas-luasnya.

\section{Ucapan Terimakasih}

Ucapan terima kasih disampaikan atas terlaksananya kegiatan ini kepada : Universitas Sultan Ageng Tirtayasa yang telah memberikan kesempatan untuk pelaksanaan kegiatan ini, Kepala Desa Tenjoayu, Kecamatan Tanara Kabupaten Serang yang telah mengijinkan pelaksanaan pelatihan pembuatan abon Bandeng. Seluruh Ibu 
PKK yang bersedia mengikuti pelatihan pembuatan abon bandeng sehingga bisa diajarkan ke warga lain di desa Tenjoayu.

\section{Referensi}

Ainurrohma, D. (2017). Pengaruh Penambahan Tepung Cangkang Kerang Hijau (Perna Viridis) Terhadap Karakteristik Cookies Kaya Kalsium (Doctoral dissertation, Universitas Brawijaya).

Astuti, K. D., Yunia, D., Mulyasari, W., Nofianti, N., \& Muttaqin, G. F. (2021). Workshop on Financial and Tax Reports for MSMEs in Tenjoayu. MOVE: Journal of Community Service and Engagement, 1(1), 5-9.

Ardya, 0. 2007. Concept "Mengenal Kemasan yang Ideal", Vol.03 Edisi 18. Jakarta:Subur Printing

Djamaludin, Aviasti Aviasti, and Otong Rukmana. 2016. "Peningkatan Kemampuan Usaha Kecil Menengah Di Wilayah Bandung Raya Dalam Pemanfaaatan Internet Sebagai Sarana Pemasaran Dan Perluasan Jangkauan Pasar." ETHOS (Jurnal Penelitian dan Pengabdian): 125.

Durdev, P B dan Maletic, V. 2011. Visual Impact of Graphic Information in the Package. Farell, Geovanne, Thamrin Thamrin, and Igor Novid. 2019. "Pelatihan Pemanfaatan Digital Marketing Dalam Pengembangan Pemasaran Dan Kewirausahaan UKM Pada Kota Sawahlunto." Suluah Bendang: Jurnal Ilmiah Pengabdian Kepada Masyarakat 19(1): 42. Proceedings of Informing Science \& IT Education Conference (InSITE) 2011.

Hafiludin, H. (2015). Analisis Kandungan Gizi Pada Ikan Bandeng Yang Berasal Dari Habitat Yang Berbeda. Jurnal Kelautan: Indonesian Journal of Marine Science and Technology, 8(1), 37-43. 